\title{
THE ROLE OF COMPLEX OF PROPHYLACTIC ARRANGEMENTS WITH THE USE OF REMINERALIZING PREPARATION AS TO ENAMEL RESISTANCE IN CHILDREN WITH DISORDERS OF TEETH FORMATION
}

\author{
Svetlana Liubarets \\ Department of pediatric and preventative dentistry \\ Bogomolets National Medical University, \\ 13 Shevchenko blvd., Kyiv, Ukraine, 01601 \\ slub@ukr.net
}

\begin{abstract}
Aim of research. To increase the resistance of teeth enamel in children with disorders of their formation by introduction of the complex of prophylactic arrangements using remineralizing preparation.

Materials and methods. The object of research is the zones of injured enamel (on the background of hypoplasia) of permanent teeth. The subject is the level of general calcium and orthophosphates in acid biopsy materials of injured teeth enamel. Methods of research: the vital coloration of enamel, transillumination, acid biopsy of enamel, photometric, statistic.

There was carried out the determination of level of calcium and orthophosphates in acid biopsy materials of injured enamel in 45 children, 6-12 years old with enamel hypoplasia. The group № 1 (21 persons) - children who underwent the complex of prophylactic arrangements that included recommendations as to the choice of means and subjects for oral cavity care and teaching the standard method of teeth brushing. The group № 2 (24 persons) - children, who additionally used remineralyzing cream on the water base with casein phosphopeptide - amorphous calcium phosphate (CPP-ACP) (Certificate on the state registration №10014/2010 of 03.12.2010).

Results. In children with chronologic enamel hypoplasia was established the low level of calcium and orthophosphates in acid biopsy materials of injured enamel. Calcium/phosphorus (Ca/P) coefficient in examined groups № 1 and № 2 was $1,26 \pm 1,14$ and $1,19 \pm 0,56$, respectively.

The high effectiveness of the offered complex of prophylactic arrangements (teaching the hygienic habits - group № 1, additional use of remineralizing cream - group № 2) is proved by the growth of macroelements content in acid biopsy materials of injured enamel in examined children. The holding of prophylactic arrangements in children of the group № 2 using remineralizing cream, favored the more essential growth of level of calcium and orthophosphates in biopsy materials comparing with group of children № 1 ( $\mathrm{p}=0,002$ and $\mathrm{p}=0,03$, respectively), and also reliably increased Ca/P coefficient ( $\mathrm{p}=0,0005)$.

Conclusions. Introduction of complex of prophylactic arrangements using remineralizing preparation in children with disorders of teeth formation favored the rise of enamel resistance as a result of growth of the level of calcium and orthophosphates in its mineral component.
\end{abstract}

Keywords: chronologic hypoplasia of dental enamel, acid biopsy of enamel, enamel calcium, enamel orthophosphates, prophylaxis.

\section{Introduction}

Prophylaxis of complications of teeth formation disorders is a topical problem of the modern child therapeutic dentistry. The teeth formation disorders including enamel hypoplasia are more than $9 \%$ among diseases that lead to the premature destruction and extraction of teeth in children [1-4]. According to the international index of dental diseases (IDC-D), enamel hypoplasia (K00.40) is assigned to the group "disorders of teeth formation" (K00.4). This injury of permanent teeth in children is a result of different endogenous and exogenous factors during the period of intrauterine development or first years of life [1].

Caries is a main complication of enamel hypoplasia $[3,5,6]$. Enamel hypoplasia appears as a result of disturbance of mineral metabolism in the period of teeth formation and development and caries injuries hard tissues of already formed teeth, first of all leading to the destruction of falsely formed hard tissues [1]. It is well-known, that teeth in the first months after cutting are most vulnerable to caries [7, 8].

At the same time the essential influence on teeth injury by caries has the mineral content of dental enamel. It was established, that 40 chemical elements participate in teeth mineralization, the most important role among which belongs to calcium, phosphorus and fluorine [9, 10]. 
The dental help for children with hypoplasia must be directed on acceleration of dental enamel mineralization processes, increase of enamel mineralization level and caries prevention in hypoplazed teeth by using remineralizing preparations [11]. The one of such preparation is remineralizing cream (RC) on the water base that includes casein phosphopeptide-amorphous calcium phosphate (CPP-ACP). The surface coatication of RC provides the additional defense of dental hard tissues, neutralizes the products of life activity of acid-creating bacteria that are contained in the dental plaque composition, neutralizes the influence of acids that enter in oral cavity from other external and internal sources [12, 13].

In the literature are presented only separate studies, devoted to the complex assessment of the problem of dental hard tissues injuries in children with disorders of teeth formation, especially to the appearance of complications (caries) and to the ways of their prevention.

\section{Aim of research}

To increase the resistance of teeth enamel in children with disorders of their formation by introduction of complex of prophylactic arrangements using remineralizing preparations.

\section{Materials and methods of research}

There were examined 45 children (II pediatric health group) [11]) 6-12 years old (the mean age of examined at first visit and in two years was 7,71 $\pm 0,95$ years and 9,8 $\pm 0,87$ years, respectively) with chronologic hypoplasia of permanent teeth enamel (defects were localized in the symmetrically placed permanent incisors, molar teeth, premolar teeth). Inclusion of children into research was carried out on condition of the informed written consent of parents and patients. Before the start of research, according to the points of "Helsinki Declaration" (2000), parents of children and older children were informed about the aim of research, methods, potential benefit and risk, possible discomfort at diagnostics and other manipulations.

For differential diagnostics of hypoplasia and caries the method of vital coloration of enamel and transillumination method were used [11].

Anamnestic data of children were received from parents or outpatient cards of clinic. Determination of forms of enamel hypoplasia in examined children was carried out according to classification of Fedorov Y. A. and co-authors (1997) [11]. Examination was realized at the department of child therapeutic dentistry and prophylaxis of dental diseases of NMU of Bogomolets O. O. and included the collection of anamnesis, interrogation of children and parents, external examination, examination of the oral cavity, acid biopsy of the injured enamel zone (Leontiev V. K., Distel V. A. (1978), in modification). Before the acid biopsy in vivo conditions all patients preliminary underwent the teeth brushing using the front brush and paste for the professional teeth brushing. Then teeth were assiduously rinsed with distilled water, dried and degreased with $96 \%$ ethyl alcohol. At procedure patient was in horizontal position. Isolation of saliva was carried out using wadding rollers and saliva suction. The tooth surface, where biopsy material was taken from, was isolated with the help of sticky ribbon with the round orifice with diameter $2 \mathrm{~mm}$, area 3,14 $\mathrm{mm}^{2}$. The biopsy materials of enamel were received using $5 \mathrm{mcl}$ of $0,1 \mathrm{M}$ hydrochloric acid $(\mathrm{HCl})$ and automatic dosing device "Human". The drops of acid were applied using the tip, left for 3 second and aspirated. Then the sticky ribbon was removed, dental surface was rinsed with water and remineralizing therapy was carried out. The enamel biopsy materials were stored in tubes with capacity 1,5 $\mathrm{ml}$. In each tube was added $1 \mathrm{ml}$ of distilled water. Determination of calcium and orthophosphates content biopsy material of injured teeth was carried out in laboratory of SI "NSCRM, NAMS of Ukraine" by photometric method, using reagents by "Human" (Germany).

For improvement of mineralizing potential of dental enamel was offered the complex of prophylactic arrangements that included:

1) teaching the oral cavity care with the further control at repeated visits;

2) recommendations as to the choice of means and subjects of hygiene;

3) regular use of remineralizing preparation.

The division of examined in groups was the following: group № $1-21$ children with the system enamel hypoplasia, who were taught the correct oral cavity care, using anticaries pasts, group № 2 - 24 children, who used reminaralizing cream (RC) besides the teaching hygienic 
habits (“Certificate on state registration № 10014/2010 of 03.12.2010). Methodology of the use corresponded to the producer's recommendations and was the following: to brush teeth with ordinary tooth paste, to rinse mouth with water, to put the thin layer of RC on teeth by finger or brush and not to close mouth during three minutes to avoid flushing of cream, then to distribute RC evenly over the whole oral cavity by tongue. It is recommended to keep RC in the oral cavity for the maximal time (minimally 5 minutes) for intensifying its action, then to remove saliva with remains of RC and do not take food and drinks during 30 minutes. It was recommended to use cream 1 time a day during month twice a year. There are presented the data for assessment of effectiveness of the offered prophylactic complex in examined children in 2 years after its introduction.

\section{Results of research}

In examined children of both groups was detected the spotted form of enamel hypoplasia.

The results of interrogation of children testified that almost none of examined possessed skills of the correct teeth brushing in full: $79 \%$ of examined brushed teeth twice a day- in evening and in the morning, $14 \%$ - once a day, $7 \%$ - irregularly.

After prophylactic arrangements in children of the group № 1 the content of calcium and orthophosphates in enamel increased (from $0,19 \pm 0,12 \mathrm{mmol} / 1$ to $0,49 \pm 0,16 \mathrm{mmol} / 1$ and from $0,18 \pm 0,07 \mathrm{mmol} / 1$ to $0,36 \pm 0,1 \mathrm{mmol} / 1$, respectively) (Table 1). In the group № 2 the content of aforesaid minerelazing components of enamel increased more significantly (from $0,22 \pm 0,12 \mathrm{mmol} / 1$ to $0,80 \pm 0,33 \mathrm{mmol} / 1$ and from $0,18 \pm 0,06 \mathrm{mmol} / 1$ to $0,55 \pm 0,26 \mathrm{mmol} / 1$, respectively). Although there were not revealed the reliable changes as to the level of calcium and orthophosphates within the examined groups before and after complex of prophylactic arrangements, it was detected the reliable increase of correspondent indices at comparison between groups ( $p=0,0002$ as to the calcium level and $\mathrm{p}=0,03$ as to the orthophosphates one, respectively).

Table 1

Calcium and orthophosphates level in biopsy materials of injured enamel of permanent teeth before and after prophylactic arrangements

\begin{tabular}{ccccc}
\hline $\begin{array}{c}\text { Group of examined } \\
\text { (number of persons) }\end{array}$ & \multicolumn{2}{c}{ Calcium, mmol/l } & \multicolumn{2}{c}{ Orthophosphates, mmol/I } \\
before & after & before & after \\
\hline $\begin{array}{c}\text { №1 } \\
(\mathrm{n}=21)\end{array}$ & $0,19 \pm 0,12$ & $0,49 \pm 0,16$ & $0,18 \pm 0,07$ & $0,36 \pm 0,1$ \\
$\begin{array}{c}\text { №2 } \\
(\mathrm{n}=24)\end{array}$ & $0,22 \pm 0,12$ & $\begin{array}{c}0,80 \pm 0,33^{*} \\
(\mathrm{p}=0,0002)\end{array}$ & $0,18 \pm 0,06$ & $\begin{array}{c}0,56 \pm 0,2^{*} \\
(\mathrm{p}=0,03)\end{array}$
\end{tabular}

Note: * - reliable difference of indices between groups before and after prophylactic arrangements

After the complex of prophylactic arrangements the positive dynamics of $\mathrm{Ca} / \mathrm{P}$ coefficient in both groups of examined was detected (Table 2). This index increased more significantly in examined of the group № 2 ( $p=0,005)$.

Table 2

Dynamics of $\mathrm{Ca} / \mathrm{P}$ coefficient in acid biopsy materials of injured enamel of permanent teeth before and after prophylactic arrangements

\begin{tabular}{ccc}
\hline $\begin{array}{c}\text { Group of examined } \\
\text { (number of persons) }\end{array}$ & before & Ca/P coefficient \\
\hline $\begin{array}{c}\text { №1 } \\
(\mathrm{n}=21)\end{array}$ & $1,26 \pm 1,14$ & $1,44 \pm 0,61$ \\
$\mathrm{~N} N 2$ & & $1,58 \pm 0,55^{* *}$ \\
$(\mathrm{n}=24)$ & $1,19 \pm 0,56$ & $(\mathrm{p}=0,005)$
\end{tabular}

Note: **-the reliable difference of indices before and after prophylactic arrangements within the one examined group 


\section{Discussion}

In examined children of both groups were revealed the spotted form of enamel hypoplasia. Spots were surface, rough at zonding, with transformed color that testifies to the amelogenesis disorder in the period of enamel formation. The more adhesion of microflora that can cause complications, especially caries, is typical for the aforesaid forms of hypoplasia as opposite to the smooth enamel surface [11]. The causes of low enamel resistance and, as a result, the increased probability of caries of permanent teeth in first years after their cutting are conditioned by the low degree of its mineralization (decreased content of calcium, phosphorus and fluorine in surface layer), increased content of water and organic component, high penetrability (at the expense large number of micropores, chinks and so on), significantly expressed disorders of surface microrelief [7, 9]. From the other side, such physiological features create optimal conditions for the processes of secondary enamel mineralization.

As it is well known, the first stages of enamel mineralization take place synchronously with formation of organic matrix or soon after it. Organic matrix determines the formation and orientation of crystals of enamel mineral component that is hydroxyapatite $\mathrm{Ca}_{10}\left(\mathrm{PO}_{4}\right)_{6}(\mathrm{OH})_{2}[7,9,11$. For the beginning there is created hydroxyapatite $\mathrm{Ca}_{8}(\mathrm{H} 3 \mathrm{O}+)_{4}\left(\mathrm{PO}_{4}\right)_{6}(\mathrm{OH})_{2}$ with molar ratio $\mathrm{Ca} / \mathrm{P}$, that is 1,33 , that testifies to the presence of vacant places or defects in bars of its crystals that is to its immaturity. The received results of examined children of both groups with disorders of teeth formation prove the disorders of enamel formation that were determined by the level of decrease of $\mathrm{Ca} / \mathrm{P}$ coefficient that was $1,26 \pm 1,14$ and1,19 $\pm 0,56$, respectively before prophylactic arrangements.

With time, under the influence of exogenous and endogenous factors, especially remineralizing preparations the hydroxyapatite with large number of calcium atoms is formed. In crystals of hydroxyapatite $\mathrm{Ca}_{10-14}\left(\mathrm{PO}_{4}\right)_{6}(\mathrm{OH})_{2}$ molar coefficient $\mathrm{Ca} / \mathrm{P}$ varies from 1,67 to 2,4. Thus, at study of calcium and phosphorus level in acid biopsy materials of enamel by spectrophotometry the index of $\mathrm{Ca} / \mathrm{P}$ coefficient in children 15-18 years old without disorders of teeth formation corresponded to the normative values $(1,89 \pm 0,06)[12]$.

At determination of indices of intravital enamel acid biopsy in children with its hypoplasia, the mean value of general calcium outcome in biopsy material was $0,78 \pm 0,02 \mathrm{mmol} / \mathrm{l}$, phosphate $-0,15 \pm 0,01 \mathrm{mmol} / 1$ [6]. Our data correspond to the aforesaid results as to the orthophosphates content in acid biopsy materials of enamel in children with enamel hypoplasia before prophylactic arrangements that were detected at the level $0,18 \pm 0,07 \mathrm{mmol} / 1$ and $0,18 \pm 0,06 \mathrm{mmol} / 1$ in examined groups №1 and № 2, respectively. As to the calcium level, its content was reliably lower in examined children comparing with Krikheli N. I. (2007), and before prescription

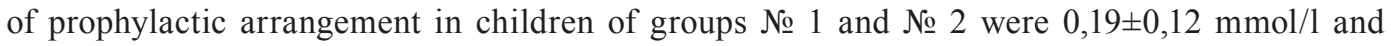
$0,22 \pm 0,12 \mathrm{mmol} / \mathrm{l}$, respectively. After prophylaxis with $\mathrm{RC}$ the calcium content in children of the group № 2 reliably increased - up to $0,80 \pm 0,33 \mathrm{mmol} / 1, \mathrm{p}=0,0002$, and reached the level of initial indices, established by Krikhely N. I. (2007).

The offered complex of prophylactic arrangements in children of the group № 2 using RC that includes casein phosphopeptide (CPP) and amorphous calcium phosphate (ACP) increased the calcium and orthophosphates level in teeth enamel in children with disorders of their formation. The index of $\mathrm{Ca} / \mathrm{P}$ coefficient in examined children reliably increased in the group № $2(\mathrm{p}=0,005)$ in two years after the complex of prophylactic arrangements and was 1,58 $\pm 0,55$.

It is well known, that phosphopeptide preserves calcium and phosphate in amorphous non-crystal state and provides the high adhesion of preparation to the teeth hard tissues, pellicle, to the plaque components and soft tissues of the oral cavity that provides the prolonged effect of preparation. CPP-ACP complex slowly releases in the medium around tooth the ions of calcium and phosphorus and provides the gradient of their concentration, necessary for displacement to the subsurface zone of demineralization nidus [13]. CPP-ACP complex is able also to modify the properties of biofilm at the expense of fixation of Streptococcus mutans molecules, increase of number of $\mathrm{Ca}^{2+}$ ions in biofilm with inhibition of its enzymatic function and provision of protein and phosphate buffering of $\mathrm{pH}$ liquid that is included in film (that inhibits the growth of acid-forming microorganisms in the conditions of excessive amount of fermented carbohydrates) [14]. 
The received results as to effectiveness of RC use in children correspond to the experimental and clinical literary data. In experiment on animals were proved that casein phosphopeptide-amorphous calcium phosphate favors remineralization of enamel [15]. RC use demonstrated the evident therapeutic effect at remineralization of non-carious injuries of the teeth hard tissues [16]. Positive influence of $\mathrm{RC}$ on the process of mineralization of the teeth hard tissues that are at the different stages of development at caries or noncarious injuries was proved by several other authors in vitro and in vivo [17-20].

Thus, our results testify that the offered complex of arrangements using $\mathrm{RC}$, directed on increase of calcium and orthophosphates level in dental enamel of children with enamel hypoplasia, can be recommended for the child contingents with aforesaid pathology.

\section{Conclusions}

1. In children of the groups № 1 and № 2 with disorders of teeth formation, especially with chronologic enamel hypoplasia was detected the low calcium content $(0,19 \pm 0,12 \mathrm{mmol} / 1$ and $0,22 \pm 0,12, \mathrm{mmol} / \mathrm{l}$, respectively) and orthophosphates content $(0,18 \pm 0,07 \mathrm{mmol} / 1$ and $0,18 \pm 0,06, \mathrm{mmol} / \mathrm{l}$, respectively) in acid biopsy materials of injured enamel that testifies to the lowering of degree of its mineralization and creates background for complications, especially caries.

2. The prophylactic arrangements in children of the group № 2 using RCi favored the essential growth of calcium and orthophosphates content in the acid biopsy materials of injured enamel comparing with children from the group № 1 ( $p=0,002$ and $p=0,03$, respectively), and also reliably decreased calcium/phosphorous coefficient in examined of the second group $(p=0,0005)$, that proves the increase of degree of enamel mineralization. The effectiveness of the offered complex in children of the group № 2 is conditioned by high remineralizing properties of cream on the water base that includes casein phosphopeptide-amorphous calcium phosphate (CPP-ACP).

\section{Acknowledgments}

We express gratitude to the workers of laboratory of SI "NSCRM, NAMS of Ukraine" for the help in realization of research.

\section{References}

[1] Bezvushko, Je. V., Ugryn, M. M., Popovych, Z. B. (2007). Porushennja rozvytku ta formuvannja zubiv. Lviv: GalDent. Ukrai'na, 72.

[2] Voljak, L. M. (2013). Profilaktyka ta likuvannja systemnoi' gipoplazii’ emali postijnyh zubiv u ditej z endemichnym zobom. Odesa, 20.

[3] Kril', I. A., Rozhko, M. M. (2011). Poshyrenist' systemnoi’ gipoplazii' emali u shkoljariv m. Ivano-Frankivs'ka. Gal. likar. Visnyk, 18 (2), 53-55.

[4] Liubarets, S. (2016). Dental status of children with the teeth formation disorders. Eureka: Health Scien, 2, 18-23. doi: 10.21303/2504-5679.2016.00089

[5] Hong, L., Levy, S. M., Warren, J. J., Broffitt, B. (2009). Association between Enamel Hypoplasia and Dental Caries in Primary Second Molars: A Cohort Study. Caries Research, 43 (5), 345-353. doi: $10.1159 / 000231571$

[6] Kriheli, N. I. (2007). Stomatologicheskij status pacientov s gipoplaziej jemali. Permskij medicinskij zhurnal, XXIV (4), 115-118.

[7] Padalka, A. I. (2015). Rezystentnist' emali postijnyh zubiv do karijesu ta osnovni sposoby i'i' diagnostyky (ogljad). Molodyj vchenyj, 2-6 (17), 644-647.

[8] Padalka, I. A., Padalka, A. I. (2008). Vysokoe kriticheskoe znachenie rN dlja jemali zubov s nezavershjonnoj mineralizaciej kak opredeljajushhij faktor rannego ih porazhenija kariesom. Innovacijni tehnologii' - v stomatologichnu praktyku. Poltava: Dyvosvit, 99.

[9] Leont'ev, V. K. (2006). Profilaktika stomatologicheskih zabolevanij. Moscow, 416.

[10] Avraamova, O. G. (2009). Profilaktika kariesa fissur putjom reguljacii sozrevanija jemali ftoridsoderzhashhimi zubnymi pastami. Moscow: Medicinskaja kniga, 193-201. 
[11] Homenko, L. A., Kisel'nikova, L. P., Smoljar, N. I., Chajkovskij, Ju. B., Vasil’ev, A. Ju., Ostapko, E. I. et. al. (2010). Terapevticheskaja stomatologija detskogo vozrasta. Kiev: Kniga pljus, Ukraina, 804.

[12] Ranjitkar, S., Rodriguez, J. M., Kaidonis, J. A., Richards, L. C., Townsend, G. C., Bartlett, D. W. (2009). The effect of casein phosphopeptide-amorphous calcium phosphate on erosive enamel and dentine wear by toothbrush abrasion. Journal of Dentistry, 37 (4), 250-254. doi: 10.1016/ j.jdent.2008.11.013

[13] Popruzhenko, T. V., Klenovskaja, M. I. (2010). Profilaktika kariesa zubov s ispol'zovaniem sredstv, soderzhashhih ftoridy, kal'cij i fosfaty. Minsk: BGMU, 42-43.

[14] Gjorgievska, E. S., Nicholson, J. W. (2010). A preliminary study of enamel remineralization by dentifrices based on RECALDENT ${ }^{\mathrm{TM}}$ (CPP-ACP) and Novamin ${ }^{\circledR}$ (calcium-sodium-phosphosilicate). Acta Odontol. Latinoam, 23 (3), 234-239.

[15] Wu, G., Liu, X., Hou, Y. (2010). Analysis of the effect of CPP-ACP tooth mousse on enamel remineralization by circularly polarized images. The Angle Orthodontist, 80 (5), 933-938. doi: 10.2319/110509-624.1

[16] Zharkova, O. A., Lobkova, O. S. (2011). Remineralizirujushhaja terapija s ispol'zovaniem GC Tooth Mousse. Sovremennaja stomatologija, 2, 42-45.

[17] Fittal', R. K., Korol'ova, Zh. V. (2014). Sravnitel'naja ocenka klinicheskoj jeffektivnosti sovremennyh preparatov dlja remineralizirujushhej terapii. Sovremennye problemy nauki i obrazovanija.

[18] Homenko, L. O., Sorochenko, G. V. (2015). Vivchennja morfologichnih zmin poverhni emali postijnih zubiv in vitro pid vplivom zasobiv ekzogennoï profilaktiki kariєsu z vmistom riznih spoluk kal'ciju. Morfologija, 9 (1), 65-70.

[19] Joshi, S., Patil, N., Choudhari, S., Kulkarni, S. (2013). Comparative evaluation of remineralizing potential of three agents on artificially demineralized human enamel: An in vitro study. Journal of Conservative Dentistry, 16 (2), 116. doi: 10.4103/0972-0707.108185

[20] Oshiro, M., Yamaguchi, K., Takamizawa, T., Inage, H., Watanabe, T., Irokawa, A. et. al. (2007). Effect of CPP-ACP paste on tooth mineralization. An FE-SEM study. J Oral Sci, 49 (2), 115-120. 